\title{
Indian Informal Sector: an Analysis
}

\author{
Dr. Muna Kalyani, Hod \& Reader \\ PG Department of Business Administration, Utkal University, Bhubaneswar \\ dr.munakalyani@yahoo.com
}

\begin{abstract}
The Indian economy is characterised by the existence of a vast majority of informal or unorganised labour employment. As per a survey carried out by the National Sample Survey Organisation (NSSO) in 200910 , the total employment in the country was of 46.5 crore comprising around 2.8 crore in the organised and the remaining 43.7 crore workers in the unorganised sector. Out of these workers in the unorganised sector, there are 24.6 crore workers employed in agricultural sector, about 4.4 crore in construction work and remaining in manufacturing and service. Informal Sector refers to economic activities i.e. production and distribution of goods and services by the operating units of the households which essentially differ from the formal sector in terms of technology, economies of scale, use of labour intensive processes, and virtual absence of the well maintained accounts. It embraces a widely dispersed multitude of operating units with high rates of birth and death and substantial mobility. It is informal in the sense that they are not regulated by government under any statute. Because of its contribution to the economy, which is quite visible and its strength in absorbing a huge portion of unemployed persons to whom the State is unable to provide adequate employment. It becomes the duty of the policy makers to device such policies which can take core of the problems faced by the informal sector workforce. Hence, there is need to monitor the size and structure of this sector and its performance over time for framing appropriate policies. In this paper an attempt to know Industry wise distribution of NDP in organized and unorganized sector and also try to attempt status of registered and unregistered enterprise in the country.
\end{abstract}

Keywords: Informal economy, Grey economy, Shadow economy, Underground economy, Unorganised workers etc.

\section{INTRODUCTION}

The informal sector plays a central role in economic development of all the countries. Particularly, developing countries one third of national income comes from this informal sector only. The informal sector reduces the unemployment problems. The entrepreneurs are in this sector for their livelihood, not for making more profit. Some informal entrepreneurs are earning more than the formal employees in our country, like vegetable vendors, agents, brokers, foot-path traders etc. Majority of the entrepreneurs are community based in this sector. In India, each community has their own business. Rural, urban and city side also community based entrepreneurs are more. For example, foot wears and beauty parlor etc. The informal sector develops the Indian economy invisibly. Most of the rural and urban people are continuing their family business, because of lack of employment opportunity, In India most of the family businesses are in the informal sector. The earned income from this sector has utilized for the purpose of their children education, family commitments, personal savings, etc. So the government should take necessary steps to convert this sector into formal.

\section{INFORMAL INDIAN ECONOMY}

About 370 million workers constituting $92 \%$ of the total workforce in a country were employed in the unorganized sector as per NSS Survey 1999-2000. It plays a fundamental role in terms of providing employment opportunity to large segment of the working force in the country and contributes to the national product significantly. The contribution of the unorganised sector to the net domestic product and its share in the total NDP at current prices has been over $60 \%$. In the matter of savings the share of household sector in the total gross domestic saving mainly unorganised sector is about three fourth.

The informal sector constitutes largest portion of the economy in terms of value addition, savings, investments etc. The share of formal sector is around $12-14$ percent in our national income while that of informal sector is more than 30 percent. 1n the case of United States, the share of corporate business is nearly 70 percent. 


\section{Dr. Muna Kalyani}

The informal forms of organizations are major players in such activities as manufacturing, construction, transport, trade, hotels and restaurants, and business and personal services. The informal sector plays a significant role in the economy in terms of employment opportunities and poverty alleviation. This sector generates income-earning opportunities for a large number of people. In India, a large section of the total workforce is still in the informal sector, which contributes a sizeable portion of the country's net domestic product.

While analyzing the composition of the Indian Economy, it is of two major sectors namely, organized and unorganized. The organized sector contributes two third to the GDP. Whereas the remaining 1/3 is by unorganized sector. The following statistics by National Account Statistics reveals the contribution of unorganised sector to the NDP.

The informal sector, informal economy, or grey economy is the part of an economy that is neither taxed, nor monitored by any form of government. Unlike the formal economy, activities of the informal economy are not included in the gross national product (GNP) and gross domestic product (GDP) of a country. The informal sector can be described as a grey in labour market. Other concepts which can be characterized as informal sector can include the black market (shadow economy, underground economy). The informal economy refers to activities and income that are partially or fully outside government regulation, taxation, and observation. The main attraction of the undeclared economy is financial. This type of activity allows employers, paid employees, and the self-employed to increase their take-home earnings or reduce their costs by evading taxation and social contributions. On the one hand, informal employment can provide a cushion for workers who cannot find a job in the formal sector. But, on the other hand, it entails a loss in budget revenues by reducing taxes and social security contributions paid and therefore the availability of funds to improve infrastructure and other public goods and services. It invariably leads to a high tax burden on registered labor. A high level of informality also can undermine the rule of law and governance. The fact that a large share of the population is openly ignoring laws, regulations and taxes can weaken the respect citizens have for the state.

The informal sector is a pervasive and persistent economic feature of most developing economies, contributing significantly to employment creation, production, and income generation. Recent estimates of the size of the informal sector in developing countries in terms of its share of nonagricultural employment range roughly between one-fifth and four-fifths. In terms of its contribution to GDP, the informal sector accounts for between $25 \%$ and $40 \%$ of annual output in developing countries in Asia and Africa.

There are various reasons why governments may be concerned about large informal sectors. These include potentially negative consequences for competitiveness and growth, incomplete coverage of formal social programs, undermining social cohesion and law and order, and fiscal losses due to undeclared economic activity. For most governments, these concerns outweigh any advantages that the informal sector offers as a source of job creation and as a safety net for the poor.

\section{THE INDIAN SCENARIO}

The Indian Economy is characterized by the existence of a vast majority of informal or unorganized labour employment. As per the Economic Survey 2007-08, 93\% of India's workforce include the self employed and employed in unorganized sector. The Ministry of Labour, Government of India, has categorized the unorganized labour force under four groups in terms of Occupation, nature of employment, specially distressed categories and service categories.

\subsection{In Terms of Occupation}

Small and marginal farmers, landless agricultural labourers, share croppers, fishermen, those engaged in animal husbandry, beedi rolling, labeling and packing, building and construction workers, leather workers, weavers, artisans, salt workers, workers in brick kilns and stone quarries, workers in saw mills, oil mills etc. come under this category.

\subsection{In Terms of Nature of Employment}

Attached agricultural labourers, bonded labourers, migrant workers, contract and casual labourers come under this. 


\subsection{In Terms of Specially Distressed Categories}

Toddy tappers, Scavengers, Carriers of head loads, Drivers of animal driven vehicles, Loaders and unloaders come under this category.

\subsection{In Terms of Service Categories}

Midwives, Domestic workers, Fishermen and women, Barbers, Vegetable and fruit vendors, News paper vendors etc. belong to this category.

In addition to these four categories, there exists a large section of unorganized labour force such as cobblers, Hamals, Handicraft artisans, Handloom weavers, Lady tailors, Physically handicapped self employed persons, Rikshaw pullers, Auto drivers, Sericulture workers, Carpenters, Tannery workers, Power loom workers and Urban poor.

Though the availability of statistical information on intensity and accuracy vary significantly, the extent of unorganized workers is significantly high among agricultural workers, building and other construction workers and among home based workers. According to the Economic Survey 2007-08 agricultural workers constitute the largest segment of workers in the unorganized sector (ie. $52 \%$ of the total workers).

As per the National Sample Survey Organization (NSSO), 30 million workers in India are constantly on the move (migrant labour) and 25.94 million women workforce has been added in the labour market from the year 2000 onwards. All the more every day 13000 Indians turn 60 years and they are expected to live another average of 17 years. Unfortunately only $10 \%$ of the Indians save for old age. The tragedy is that the existing social security legislations cover only $8 \%$ of the total work force of 459 million in India.

The latest report of the NSSO uploaded by the close of May 2011 about the casual workers in India between 2004-05 and 2009-10 compared to that of the period between 1999-2000 and 2004-05 very clearly shows that there is significant increase in the number of casual workers and decline in the number of regular workers.

This report shows a substantial shift between 1999-00 and 2009-10 in the structure of the labour force which can be broadly divided in to self employed, regular, and casual workers. (casual workers are employees who do not enjoy the same benefits and security as tenured employees. All daily wage employees and some categories of contract employees are casual labourers.)

All these NSSO reports are clear evidences to prove that the labour market of India has been undergoing tremendous transformations, including growth of informal sector activities, deterioration in the quality of employment (in terms of job security, terms and conditions at work), Weakening of worker organizations and collective bargaining institutions, marked decline in social security etc. To a greater extent, these transformation could be related to the ongoing globalization process and the resultant efforts on the part of employers to minimize the cost of production to the lowest levels. It is also evident that most of these outcomes are highly correlated and mutually reinforcing. A closer analysis suggests that the growing informalisation of labour market has been central to most of these transformations, which inter alia highlights the utility of understanding the growth of unorganized sector in India and its implications.

Many thought that India's growth could do no wrong, and took the administrative versions and interpretations for granted. Now it comes to a point that none of these can be taken for granted. Growth is slow, inflation is structural and structure of employment is not enough to cater to the growing labour force.

\section{IMPORTANCE OF INFORMAL SECTOR IN INDIAN ECONOMY}

About 370 million workers constituting $92 \%$ of the total workforce in a country were employed in the unorganized sector as per NSS Survey 1999-2000. It plays a vital role in terms of providing employment opportunity to large segment of the working force in the country and contributes to the national product significantly. The contribution of the unorganised sector to the net domestic product and its share in the total NDP at current prices has been over $60 \%$. In the matter of savings the share of household sector in the total gross domestic saving mainly unorganised sector is about three fourth. The informal sector constitutes largest portion of the economy in terms of value addition, savings, investments etc. The share of formal sector is around $12-14$ percent in our national income while that 
of informal sector is more than 30 percent. 1n the case of United States, the share of corporate business is nearly 70 percent.

The informal forms of organizations are major players in such activities as manufacturing, construction, transport, trade, hotels and restaurants, and business and personal services. The informal sector plays a significant role in the economy in terms of employment opportunities and poverty alleviation. This sector generates income-earning opportunities for a large number of people. In India, a large section of the total workforce is still in the informal sector, which contributes a sizeable portion of the country's net domestic product.

While analyzing the composition of the Indian Economy, it is of two major sectors namely, organized and unorganized. The organized sector contributes two third to the GDP. Whereas the remaining 1/3 is by unorganized sector. The following statistics by National Account Statistics reveals the contribution of unorganised sector to the NDP.

\subsection{Growing Prominence of Unorganized Sector in India}

Predominance of informal employment has been one of the central features of the labour market scenario in India. While the sector contributes around half of the GDP of the county, its dominance in the employment front is such that more than $90 \%$ of the total workforce has been engaged in the informal economy. As per the latest estimation of a Sub-committee of the National Commission for Enterprises in the Unorganized Sector (NCEUS), the contribution of unorganized sector to GDP is about $50 \%$ (NCEUS 2008).

This national level pattern of informal workers occupying around $90 \%$ of the workforce is more or less similar in the case of most of the prominent states in the country. Among the unorganized sector workers, a considerable proportion (about 65\%) is engaged in agricultural sector, which in turn indicates the prominence of rural segment in the informal economy.

The growth of formal employment in the country has always been less than that of total employment, indicating a faster growth of employment in the informal sector. Available data suggests that within the formal sector also the proportion of informal / unorganized workers are on the increase. For instance, by providing a comparison of the NSSO Employment Data for $55^{\text {th }}$ and $61^{\text {st }}$ Rounds (for 1999-2000 and 2004-05 respectively) the NCEUS (2007) explains that the country is currently in a state of "informalisation of the formal sector", where the entire increase in the employment in the organized sector over this period has been informal in nature.

It is widely acknowledged that the informal sector in India suffers from a low productivity syndrome, compared to the formal sector. The prominent features of the sector are lower real wages and poor working / living conditions.

Further, the sector is characterized by excessive seasonality of employment (especially in the farm sector), preponderance of casual and contractual employment, atypical production organizations and work relations, absence of social security measures and welfare legislations, negation of social standards and worker rights, denial of minimum wages and so on. Poor human capital base (in terms of education, skill and training) as well as lower mobilization status of the work force further add to the vulnerability and weaken the bargaining strength of workers in the informal sector. Thus, the sector has become a competitive and low cost device to absorb labour, which cannot be absorbed elsewhere, whereas any attempt to regulate and bring it into more effective legal and institutional framework is perceived to be impairing the labour absorbing capacity of the sector.

With the advent of globalization and resultant reorganization of production chains led to a situation where production systems are becoming increasingly atypical and non-standard, involving flexible workforce, engaged in temporary and part-time employment, which is seen largely as a measure adopted by the employers to reduce labour cost in the face of stiff competition. No doubt, it obviously indicates that these flexible workers in the new informal economy are highly vulnerable in terms of job security and social protection, as they are not deriving any of the social protection measures stipulated in the existing labour legislations. The insecurities and vulnerabilities of these modern informal sector labour are on the rise, as there is a visible absence of worker mobilization and organized collective bargaining in these segments owing to a multitude of reasons. 
The alarming expansion of informal sector, in recent times, has adversely affected employment and income security for the larger majority of the workforce, along with a marked reduction in the scale of social welfare / security programme.

In our "global" cities such as Bangalore, which are being show-cased as the new faces of an affluent and vibrant India, there are lakhs of people who rely on manual labour for their own livelihood. The housemaids, security guards, construction workers, garment workers, cobblers, beedi workers, agarbati workers, drivers and many others have a very different story to tell. Their incomes have not grown at the staggering rate of their employers; indeed adjusted for inflation their incomes have often fallen over the last two and half decades, driving them into deeper poverty.

\subsection{The Major Characteristics of the Unorganized Workers}

1. The unorganized labour is overwhelming in terms of its number range and therefore they are omnipresent throughout India.

2. As the unorganized sector suffers from cycles of excessive seasonality of employment, majority of the unorganized workers does not have stable durable avenues of employment. Even those who appear to be visibly employed are not gainfully and substantially employed, indicating the existence of disguised unemployment.

3. The workplace is scattered and fragmented.

4. There is no formal employer - employee relationship

5. In rural areas, the unorganized labour force is highly stratified on caste and community considerations. In urban areas while such considerations are much less, it cannot be said that it is altogether absent as the bulk of the unorganized workers in urban areas are basically migrant workers from rural areas.

6. Workers in the unorganized sector are usually subject to indebtedness and bondage as their meagre income cannot meet with their livelihood needs.

7. The unorganized workers are subject to exploitation significantly by the rest of the society. They receive poor working conditions especially wages much below that in the formal sector, even for closely comparable jobs, ie, where labour productivity are no different. The work status is of inferior quality of work and inferior terms of employment, both remuneration and employment.

8. Primitive production technologies and feudal production relations are rampant in the unorganized sector, and they do not permit or encourage the workmen to imbibe and assimilate higher technologies and better production relations. Large scale ignorance and illiteracy and limited exposure to the outside world are also responsible for such poor absorption.

9. The unorganized workers do not receive sufficient attention from the trade unions.

10. Inadequate and ineffective labour laws and standards relating to the unorganized sector.

11. Heterogeneity in activities;

12. Easier entry and exit than in the formal sector;

13. Usually minimal capital investment; little or no division between labour and capital;

14. Mostly labour intensive work, requiring low-level skills; there is usually no formal training as workers learn on the job;

15. Labour relations based on casual employment and or social relationships as opposed to formal contracts; employer and employee relationship is often unwritten and informal with little or no rights;

16. Due to their isolation and invisibility, workers in the informal sector are often largely unaware of their rights, cannot organise them and have little negotiating power with their employers and intermediaries (ILO 2000).

\subsection{The Role of Human Capital in Contributing to Economic Development}


Many workers in developing countries are confined to the informal economy because of limited educational opportunities and rudimentary work skills. The International Labor Organization described this workforce segment as "low skill, low productivity, low wage, low investment" (International Labour Organization (ILO), 2007)

\subsection{The informal sector contribution}

The contribution of unorganized sector in net Domestic Product is $56.7 \%$ in 2002-03. Thus, the major chunk of NDP is provided by the unorganized sector.

\subsection{Sector Share in Net Domestic Product (2002-03)}

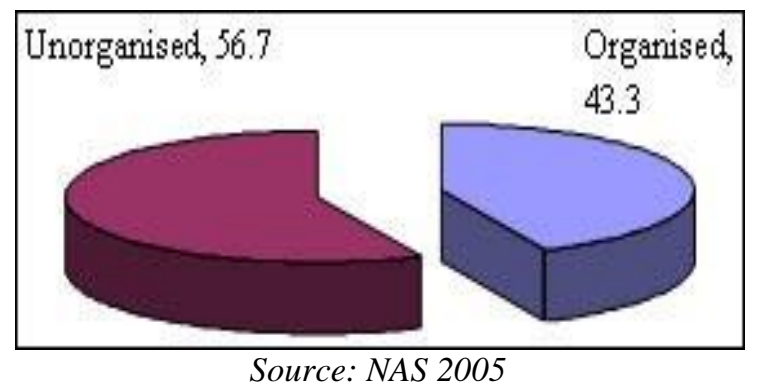

Main Industries of Informal Activities, Sector wise distribution of different industries (2002-03)

\begin{tabular}{|l|c|c|c|}
\hline \multicolumn{1}{|c|}{ Industry } & $\begin{array}{c}\text { Organized sector } \\
\text { (\% of NDP) }\end{array}$ & $\begin{array}{c}\text { Unorganized sector } \\
(\% \text { of NDP })\end{array}$ & Total \\
\hline Agriculture, forestry, fishing & 4.1 & 95.9 & 100.0 \\
\hline $\begin{array}{l}\text { Mining, manufacturing, electricity and } \\
\text { construction }\end{array}$ & 60.5 & 39.5 & 100.0 \\
\hline Services & 53.1 & 46.9 & 100.0 \\
\hline Total & $\mathbf{4 3 . 3}$ & $\mathbf{5 6 . 7}$ & $\mathbf{1 0 0 . 0}$ \\
\hline
\end{tabular}

Source: NAS 2005

Industry wise distribution of NDP in organised and unorganized sectors shows that in agriculture sector, the share of organized sector is only $4 \%$ whereas $96 \%$ share is contributed by the unorganized sector. Due to this reason, the informal activities are studied in the non agricultural sectors only. In mining, manufacturing sector $60 \%$ share in NDP is of organised sector while $40 \%$ shore is contributed by the unorganised sector. In service sector contribution of organized sector is $53 \%$ while $47 \%$ of the share is contributed by unorganised sector.

\subsection{Social Security Measures}

It is rightly true that when independent India's constitution was drafted, social security was specially included in List III to Schedule VII of the constitution and it was made as the concurrent responsibility of the central and state governments. A number of directive principles of state policy relating to aspects of social security were incorporated in the Indian constitution. The initiatives in the form of Acts such as the Workmen's Compensation Act (1923), the Industrial Disputes Act (1947), the Employees State Insurance Act (1948), the Minimum Wages Act (1948), the Coal Mines Provident Funds and Miscellaneous Provisions Act (1948), The Employees Provident Fund and Miscellaneous Provisions Act (1952), the Maternity Benefit Act (1961), the Seamen's Provident Fund Act (1966), the Contract Labour Act (1970), the Payment of Gratuity Act (1972), the Building and Construction Workers Act (1996) etc. reveal the attention given to the organized workers to attain different kinds of social security and welfare benefits. Though it has been argued that the above Acts are directly and indirectly applicable to the workers in the unorganized sector also, their contribution is very negligible to the unorganized workers.

Inspite of the fact that not much has been done in providing social security cover to the rural poor and the unorganized labour force, the country has made some beginning in that direction. Both the central and state governments have formulated certain specific schemes to support unorganized workers which fails in meeting with the real needs and requirements of the unorganized sector labour force.

This becomes clear even when the highly proclaimed National Rural Employment Guarantee Act 2005 (NREGA), though it is a breakthrough, doesn't have common wage in different states and limits itself only to hundred day's work for those registered worker under the Act. What about the rest of the 
days in an year? As per this Act, the work guarantee applies in rural areas only, what about the urban poor?

And looking at the recent Unorganized Sectors' Social Security Act (2008), one really wonders if there is any provision for an unorganized worker in this Act other than some guidelines about the available social security schemes in the country. How can it be called an Act unless it has the legal binding and provisions of rights to work and entitlements under it? Here as per the Act nothing is mentioned about what constitutes appropriate and adequate social security for the vast mass of unorganized workers and their dependents, what eligibility criteria, if any, ought to be prescribed, what will be the scale of benefits that the workers and their families are entitled to receive and under what conditions, what will be the funding arrangements that must be put in positions to meet the cost of social security and so on. Aren't the unorganized workers of this country entitled to receive, in this $60^{\text {th }}$ year of our Republic, minimum standards of social security and labour rights, on the scale and spread adumbrated in the relevant ILO convention drawn up more than 50 years ago? Therefore, this law which does not deal with the issue of unemployment, its regulation, wages, and conditions of work and so on is not merely incomplete but dysfunctional if it proceeds to deal with social security on a standalone basis. The Act, actually, suffers from a serious lack of legislative policy and intent. Ultimately this Act is an eye wash which has neither the capacity to address nor the inbuilt provision to provide solutions to the needs of the unorganized sector. Even the provisions and procedure of the Minimum Wages Act (1948) is so vague and futile that different states of India have fixed abysmally meagre wages and that too with so much of variations from state to state.

In fact a comprehensive Act, catering to the security needs of the unorganized sector such as Food, Nutrition, Health, Housing, Employment, Income, Life and accident, and old age remains a dream in India. Still the cries of the unorganized sector goes unattended with the governments laying red carpets for the corporate and so called investors at the expense and sacrifice of the working class.

\section{Conclusion}

The evidence we have presented is broadly consistent with the dual view of informality: informal firms stay permanently informal, they hire informal workers for cash, buy their inputs for cash, and sell their products for cash, they are extremely unproductive, and they are unlikely to benefit much from becoming formal. This approach generates the strong prediction that the cure for informality is economic growth. The evidence strongly supports this prediction: informality declines, although slowly, with development. This approach suggests that structural policies designed to promote formality should be introduced with caution. Their wisdom depends, in part on whether they encourage formalization, or discourage informal activity. Thus the simplification of business registration advocated by De Soto (1989) is probably a good idea, even though the evidence suggests that it is unlikely to have large benefits. On the other hand, we are skeptical of all policies that might tax or regulate informal firms. Rather than encourage informal firms to become formal, such policies may have the effect of driving them out of business, leading to poverty and destitution of informal workers and entrepreneurs. The recognition of the fundamental fact that informal firms are extremely inefficient recommends extreme caution with policies that impose on them any kind of additional costs. There is accumulating evidence that growth that kills the informal sector is driven by the formation and expansion of formal firms managed by educated entrepreneurs. Uneducated entrepreneurs - in both informal and formal sectors - generally run small and inefficient firms; educated entrepreneurs and managers run larger and more-efficient firms. This is the dark side of dualism: informal economies are so large in poor countries because their entrepreneurs are so unproductive. The evidence suggests that an important bottleneck to economic growth is not the supply of better-educated workers; indeed, at least on many observable characteristics the workers are rather similar in informal and formal firms. Rather, the bottleneck is the supply of educated entrepreneurs - people who can run productive businesses. These entrepreneurs create and expand modern businesses with which informal firms, despite all their benefits of avoiding taxes and regulations, simply cannot compete. This is how the informal economy dies out in the process of development. From this perspective, the policy message for how to grow the formal economy and shrink the informal one is to increase - whether through immigration or education and training - the supply of educated entrepreneurs.

\section{REFERENCES}


[1] Bhalla Sheila (2007), "Policy Paper On Definitional and Statistical Issues Relating to Unorganised and Workers in Informal Employment", NCEUS.

[2] Central Statistical Organization (1989): National Accounts Statistics - Sources and Methods, Department of Statistics, Government of India

[3] Central Statistical Organization (2006). New Series on National Accounts Statistics (base year 1999-2000), Department of Statistics and Programme Implementation, Government of India

[4] Gerxhani, K. (2004), "The informal sector in developed and less developed countries: A literature survey", Public Choice 120: 267-300.

[5] Hart K. (1973), "Informal income opportunities and urban employment in Ghana", Journal of Modern African Studies 11: 61-89.

[6] Jolly R. (2006), "Hans Singer: The gentle giant", Presented as a lecture in Geneva in the ILO on May 18th, 2006.

[7] Kundu, A. and Sharma, A.N. (eds) (2001), "Informal Sector in India: Perspectives and Policies", Institute of Human Development, Delhi.

[8] Mitra, A. (2001), "Employment in the informal sector", in A. Kundu and A.N. Sharma (eds) "Informal sector in India: perspectives and policies", Institute of Human Development, Delhi.

[9] NSSO 2001a. "Employment-Unemployment Situation in India 1999-2000", Round 55th , Report No. 458 - I and II (55/10/2), Ministry of Statistics and Program Implementation. Government of India. New Delhi. NSSO 2006a. "Employment-Unemployment Situation in India 2004 - 2005", Round 61st , Report No. 515 - I and II (61/10/1\&2), Ministry of Statistics and Program Implementation. Government of India. New Delhi.

[10] Papola, T.S. (1981), "Urban informal sector in a developing economy”, Vikas Publishing House, New Delhi.

[11] Raveendran, G. (2005), "Estimating Employment in the Informal Economy through Labour Force Surveys: An Indian Attempt", Report of the Eighth Meeting of the Expert Group on Informal Sector Statistics.

[12] Raveendran, G., Murthy, SVR. and Naik, A.K. (2006), "Redefining of Unorganized Sector in India", Paper No-2, Paper presented at Delhi Group meeting, New Delhi.

[13] Sastry, N.S. (2004), Estimating Informal Employment \& Poverty in India, Discussion paper series 7, Human Development Resource Centre, UNDP, India.

[14] Swaminathan, M. (1991), "Understanding the informal sector: A survey", WIDER WP 95. Finland UN (1993), "System of National Accounts", United Nations.

[15] Unni, Jeemol and Murthy, S.V.R. (2005), "Review of Current Definitions of the Unorganised and Informal Sector in India: Suggestions for Consistent Definition", NCEUS. 